\title{
MENINGKATKAN KEMAMPUAN MEMBACA PERMULAAN MELALUI \\ PEMADUAN MODEL PICTURE AND PICTURE DAN PERMAINAN \\ KARTU HURUF PADA SISWA KELAS I SDN 2 BULANGO \\ UTARA KABUPATEN BONE BOLANGO
}

\author{
Ruslin W. Badu, Winda Saleh \\ Pendidikan Dasar Pascasarjana Universitas Negeri Gorontalo
}

\begin{abstract}
ABSTRAK
Penelitian ini bertujuan Untuk Mengetahui (1) Model pembelajaran picture and picture dapat meningkatkan kemampuan membaca permulaan, 2) Untuk Mengetahui penerapan permainan kartu huruf dalam meningkatkan kemampuan membaca permulaan, 3) Untuk Mengetahui model picture and picture dan permainan kartu huruf dapat meningkatkan kemampuan membaca permulaan. Metode yang digunakan dalam penelitian ini adalah metode penelitian tindakan kelas yang dilaksanakan dalam dua siklus dan setiap siklus terdiri dari 2 kali pertemuan. Sebagai kesimpulan dari penelitian ini adalah: Hasil Penelitian pada observasi awal meningkat pada siklus I tetapi belum mencapai criteria ketuntasa, pada siklus II meningkat dan mencapai criteria ketuntasan. Hasil pengamatan akvitas siswa dalam pembelajaran siklus I pada kriteria sangat baik dan baik belum mencapai, pada siklus II mencapai ketuntasan, Hasil pengamatan kegiatan guru dalam pembelajaran. Pada siklus I kriteria sangat baik dan baik belum mencapai pada siklus II mencapai ketuntasan. Berdasarkan hasil capaian dinyatakan bahwa kriteria tuntas atau indikator tercapai.
\end{abstract}

Kata Kunci: Permainan, Kartu huruf, Model Picture And Picture, Membaca Permulaan

\section{A.PENDAHULUAN}

Pendidikan merupakan hal yang sangat penting dan mendasar yang harus dimiliki oleh semua manusia. Pendidikan sangat bermanfaat bagi kehidupan manusia, karena dengan adanya pendidikan Pedagogika.fup@ung.ac.id P-ISSN : 2086-4469 manusia akan memperoleh wawasan ilmu pengetahuan yang sangat luas. Guru mempunyai tanggungjawab untuk mengembangkan potensi peserta didiknya sesuai dengan kemampuannya. Menurut Sylvia Chong dan Horn Mun Cheah, (2009:

E-ISSN : 2716-0580 
4) mengatakan "guru yang sukses percaya bahwa semua siswa mereka mampu belajar mengumpulkan informasi, memahami materi yang kompleks, mengetahui dan dapat memecahan masalah, kritis, membangun perspektif alternatif, sintesis, membandingkan dan menganalisis bukti."

Keberhasilan belajar siswa dalam mengikuti proses kegiatan belajar mengajar di sekolah sangat di tentukan oleh penguasaan kemampuan membaca. Siswa yang tidak mampu membaca dengan baik akan mengalami kesulitan dalam mengikuti kegiatan pembelajaran untuk semua mata pelajaran. Akibatnya, kemajuan belajarnya juga lamban jika dibandingkan dengan siswa yang tidak mengalami kesulitan dalam membaca.

Berdasarkan observasi bulan februari 2018 bahwa siswa kelas 1 masih banyak yang belum mampu membaca. dari 20 siswa, terdapat siswa yang sudah mampu membaca dengan lancar tanpa mengeja 5 siswa, membaca dengan sedikit mengeja dan 15 siswa lainnya masih belum mampu membaca dan mengeja, bahkan terdapat siswa yang masih belum sama sekali mengenal huruf, kesulitan membedakan huruf $d$ dengan huruf $b$ dan huruf $\mathrm{p}$ dengan $\mathrm{q}$ seperti budi di baca dubi, sulit mengucapkan kata yang panjang seperti ibu pergi ke rumah dibaca ibu ke rumah, sulit mengucapkan intonasi dengan benar seperti siswa dalam membaca tidak memperhatikan tanda baca (koma, spasi, titik), sulit mempelajari hubungan antara bentuk huruf dan bunyi huruf, serta masih di bantu guru dalam membaca.

Rendahnya kemampuan membaca siswa kelas I disebabkan oleh beberapa hal, di antaranya hasil ujian tengah semester masih terdapat siswa yang memiliki kemampuan membaca rendah, hal ini di sebabkan oleh ketidakmampuan siswa seperti banyak siswa yang tidak mengikuti sekolah jenjang taman kanak-kanak, kurangnya motivasi diri dalam membaca, kurangnya perhatian dari orangtua dan Faktor IQ atau Inteligensi. 


\section{Pemecahan Masalah}

Dalam memecahkan masalah tentang rendahnya Kemampuan membaca permulaan pada siswa kelas I SDN yang berjumlah 20. adapun pemecahan masalah dilakukan dengan langkah-langkah sebagai berikut a. Guru menyampaikan kompetensi yang ingin dicapai, b. Guru menyajikan materi sebagai pengantar, c. Guru menunjukkan gambar-gambar kegiatan berkaitan dengan materi, d. Guru menunjuk siswa secara bergantian mengurutkan gambar-gambar dan huruf, e. Guru menanyakan alasan/dasar pemikiran urutan gambar tersebut, f. Dari alasan/urutan gambar tersebut guru memulai menanamkan konsep/materi sesuai dengan kompetensi yang ingin dicapai, g. Kesimpulan/rangkuman.

\section{Membaca Permulaan}

Sesuai dengan namanya,
membaca permulaan merupakan
membaca tahap awal belajar membaca.

Menurut Farida Rahim (2005:2) membaca permulaan berlangsung pada kelas-kelas awal, yaitu SD kelas I, II dan III. Penekanan membaca pada tahap ini adalah proses perseptual, yaitu pengenalan korespondensi rangkaian huruf dengan bunyi-bunyi bahasa. Sementara proses memahami makna (meaning) lebih ditekankan di kelas-kelas tinggi.

\section{Proses Membaca Permulaan Kelas Rendah Sekolah Dasar}

Kemampuan membaca yang diperoleh dalam membaca permulaan akan sangat berpengaruh terhadap kemampuan membaca selanjutnya, sebagai kemampuan yang mendasari kemampuan berikutnya maka kemampuan membaca permulaan benar-benar memerlukan perhatian guru. Kemampuan membaca sangat diperlukan untuk setiap orang yang ingin memperluas pengetahuan dan pengalaman, mempertinggi daya pikir, mempertajam penalaran untuk memcapai kemajuan dan peningkatan diri, Guna membekali kemampuan dasar siswa, maka guru haruslah berusaha sungguh-sungguh agar dapat memberikan dasar kemampuan membaca yang memadai kepada anak 
didik. Hal itu akan terwujud melalui pelaksanaan pembelajaran dengan baik. Untuk dapat melaksanakan pembelajaran secara baik, perlu ada perencanaan, baik mengenai materi, metode maupun pengembangannya, (Jurnal Kreatif Tadulako Online Vol. 3 No. 1 ISSN 2354-614X).

\section{Permainan Kartu Huruf}

Bermain adalah pekerjaan anak-anak dan anak-anak sangat gemar bermain. Dalam bermain anak mengembangkan keterampilan memecahkan masalah dengan mencoba berbagai cara dengan mengerjakan sesuatu dan memilih dan menentukan cara yang paling tepat.

Penggunaan kartu huruf ini sangat menarik perhatian siswa dan sangat mudah digunakan dalam pengajaran membaca permulaan. Selain itu kartu huruf juga melatih kreatifitas siswa dalam menyusun kata-kata sesuai dengan keinginannya.

Kartu huruf merupakan media yang termasuk pada jenis media grafis atau media dua dimensi, yaitu media yang mempunyai ukuran panjang dan lebar. Menurut Wibawa (Ratnasari, Pedagogika.fup@ung.ac.id P-ISSN : 2086-4469
2003:16) kartu huruf biasanya berisi huruf-huruf, gambar atau kombinasinya dan dapat digunakan untuk mengembangkan perbendaharaan kata dalam pelajaran bahasa pada umumnya dan bahasa asing khususnya.

\section{Model Pembelajaran Picture and Picture}

Model pembelajaran adalah suatu rencana atau pola yang dapat digunakan untuk membentuk kurikulum (rencana pembelajaran jangka panjang), merancang bahanbahan pembelajaran, dan membimbing pembelajaran di kelas atau yang lain (Joyce \& Weil dalam Rusman, 2011: 133).

Menurut Agus (2011:125) Picture and picture yaitu suatu metode belajar yang menggunakan gambar dalam bentuk potongan-potongan untuk dipasangkan serta diurutkan menjadi gambar yang utuh. Pendapat dari Shoimin (2014:43) yang menyatakan bahwa pembelajaran dengan model picture and picture, siswa akan lebih berkonsentrasi dan merasa asyik karena tugas yang E-ISSN : 2716-0580 
diberikan oleh berkaitan dengan permainan mereka sehari-hari, yakni bermain gambar.

Sedangkan Kurniasih dan Berlin (2015:13) menyatakan bahwa pembelajaran dengan model picture and picture melatih siswa untuk berpikir logis, membantu siswa belajar dengan memberikan kebebasan siswa dalam praktik berpikir, dan yang tidak kalah penting, model picture and picture membantu guru dalam mengetahui kemampuan yang dimiliki masing-masing siswanya.

Berdasarkan beberapa pendapat disimpulkan bahwa model picture and picture adalah model yang menggunakan gambar dalam bentuk potongan-potongan untuk dipasangkan serta diurutkan menjadi gambar yang utuh, dengan menggunakan gambar siswa lebih berkonsentrasi dan kegiatan lebih menarik.

\section{Teori Membaca Permulaan}

\section{Teori Goodman}

\begin{tabular}{cc}
\multicolumn{3}{c}{ Teori membaca adalah rincian } \\
yang sistematis tentang proses
\end{tabular} membaca dan faktor-faktor yang mempengaruhi, yang diharapkan dapat menggambarkan secara teknis dan jelas bagaimana proses membaca itu berlangsung. Banyak manfaat yang dapat kita ambil dengan mempelajari teori membaca. Bagi orang awam atau pembaca umumnya, manfaat teori membaca adalah untuk mengetahui dan meningkatkan kemampuan membacanya.

Berdasarkan pendekatan konseptual, muncul teori membaca Goodman. memandang membaca "sebagai proses komunikasi" dengan dasar titik tolaknya pada linguistik terapan. Linguistik terapan yaitu sebagai sesuatu yang mengandung pesan.

\section{B.METODE PENELITIAN}

Penelitian ini merupakan penelitian tindakan kelas (PTK), yang dilakukan sebagai upaya dalam menerapkan model pembelajaran picture and picture untuk meningkatkan kemampuan membaca awal pada siswa kelas I di SDN 2 Bulango Utara Kabupaten Bone Bolango. Dalam penelitian ini dibagi dalam 3 variabel yakni variabel input, variabel proses, dan variabel output.

E-ISSN : 2716-0580 
Menurut Arikunto (2007:16) secara garis besar ada empat tahapan dalam penelitian tindakan kelas yaitu: perencanaan,pelaksanaan, pengamatan, dan refleksi yang dilaksanakan dalam dua siklus. Berikut adalah desain penelitian kelas yang digunakan peneliti yaitu:

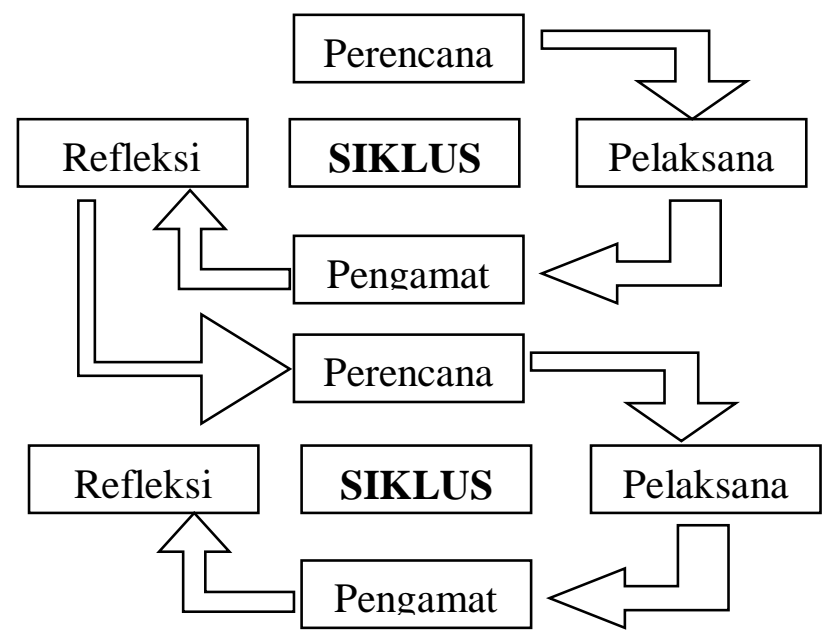

Teknik Pengumpulan Data

ada beberapa teknik pengumpulan data yang digunakan yaitu observasi, tes, dan dokumentasi.

\section{Indikator keberhasilan Tindakan}

Untuk mengetahui keberhasilan, pencapaian tujuan dalam penelitian di siswa kelas I di SDN 2 Bulango Utara Kabupaten Bone Bolango, maka kemampuan membaca awal akan meningkat. Penelitian ini dikatakan berhasil jika setelah digunakan Model picture and picture kemampuan membaca awal meningkat, siswa yang memperoleh hasil belajar minimal 75 akan meningkat dari $44.44 \%$ menjadi $85 \%$.

\section{C.HASIL DAN PEMBAHASAN}

Penerapan model pembelajaran picture and picture dan permainan kartu huruf yang digunakan pada pembelajaran, bertujuan untuk mengetahui kemampuan membaca permulaan dalam pembelajaran pada siklus I dan II, serta kegiatan guru dan aktivitas siswa saat pembelajaran. Berikut disajikan data antar siklus berikut ini:

Tabel 1 Nilai kemampuan Membaca

Permulaan (Capaian Ketuntasan)

\begin{tabular}{|c|l|c|c|c|}
\hline No & $\begin{array}{c}\text { Uraian } \\
\text { Pencapai } \\
\text { an Hasil }\end{array}$ & $\begin{array}{c}\text { Observa } \\
\text { si Awal }\end{array}$ & $\begin{array}{c}\text { Nilai } \\
\text { Siklus } \\
\text { I }\end{array}$ & $\begin{array}{c}\text { Nilai } \\
\text { Siklus } \\
\text { II }\end{array}$ \\
\hline 1 & Tuntas & $25 \%$ & $60 \%$ & $95 \%$ \\
\hline 2 & $\begin{array}{l}\text { Tidak } \\
\text { Tuntas }\end{array}$ & $75 \%$ & $40 \%$ & $5 \%$ \\
\hline
\end{tabular}


Hasil capaian ketuntasan klasikal siswa dapat divisualisasikan dalam grafik diagram sebagai berikut

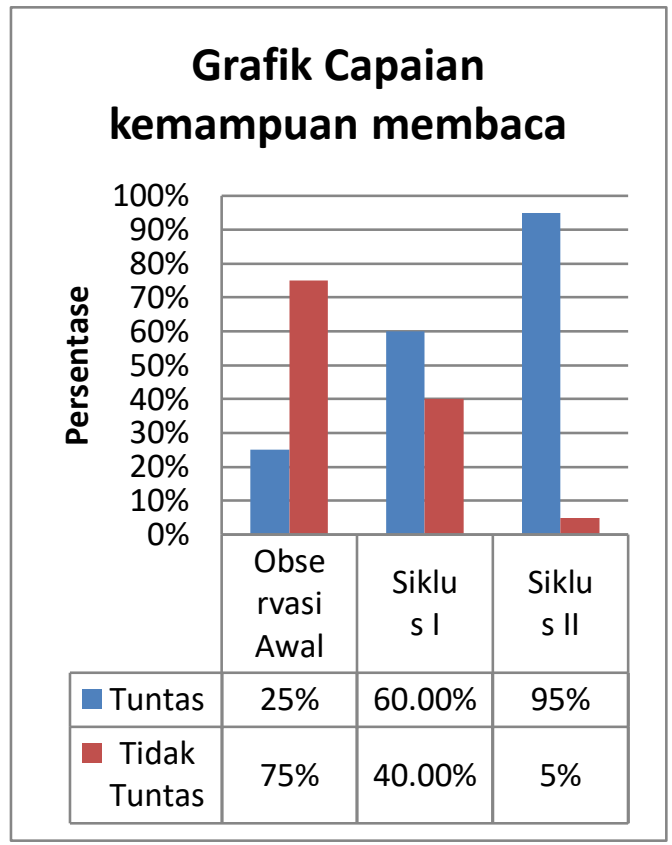

Berdasarkan pada tabel, dan grafik terlihat capaian ketuntasan siswa semakin mengalami peningkataj yakni observasi awal dengan capaian ketuntasan $25 \%$ dan yang tidak tuntas $75 \%$. Pada siklus I mengalami peningkatan dari sebelumnya, capaian ketuntasan sebesar $60 \%$, dan belum mencapai batas tuntas minimal mencapai $40 \%$. Pada siklus II terjadi kenaikan persentase dibandingkan siklus I yaitu capaian ketuntasan sebesar $95 \%$ dan $5 \%$ belum mencapai ketuntasan

Tabel 2 Hasil Pengamatan Aktivitas

Siswa dalam Pembelajaran

\begin{tabular}{|c|l|c|c|}
\hline No & Kategori & Siklus I & $\begin{array}{c}\text { Siklus } \\
\text { II }\end{array}$ \\
\hline 1 & $\begin{array}{l}\text { Sangat } \\
\text { Baik }\end{array}$ & $12 \%$ & $45 \%$ \\
\hline 2 & Baik & $21 \%$ & $41 \%$ \\
\hline 3 & Cukup & $38 \%$ & $14 \%$ \\
\hline 4 & Kurang & $29 \%$ & - \\
\hline
\end{tabular}

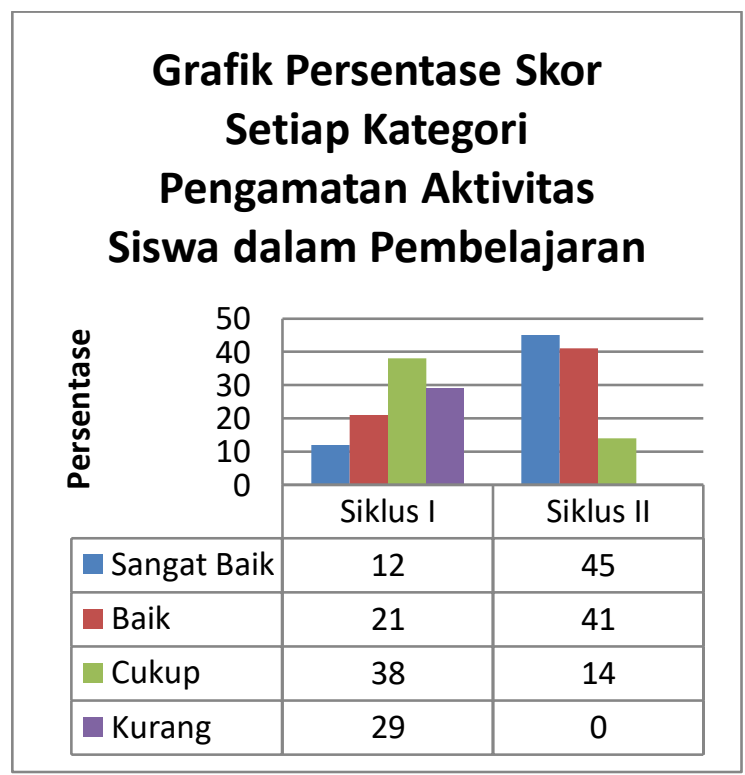

Hasil pengamatan aktivitas siswa dalam belajar menunjukkan peningkatan dari setiap siklus yang dilakukan. Hal ini berarti aktivitas siswa pada saat proses pembelajaran lebih baik dengan presentasi 
mengalami perubahan yang cukup baik pada mengalami peningkatan yakni pada setiap aspek, karena siswa menjadi lebih kategori sangat baik mencapai $6 \%$ aktif dalam proses pembelajaran.

Tabel 3. Hasil Pengamatan Kegiatan

Guru dalam Pembelajaran

\begin{tabular}{|c|l|c|c|}
\hline No & Kategori & Siklus I & $\begin{array}{c}\text { Siklus } \\
\text { II }\end{array}$ \\
\hline 1 & $\begin{array}{l}\text { Sangat } \\
\text { Baik }\end{array}$ & $6 \%$ & $40 \%$ \\
\hline 2 & Baik & $22 \%$ & $46 \%$ \\
\hline 3 & Cukup & $38 \%$ & $14 \%$ \\
\hline 4 & Kurang & $34 \%$ & - \\
\hline
\end{tabular}

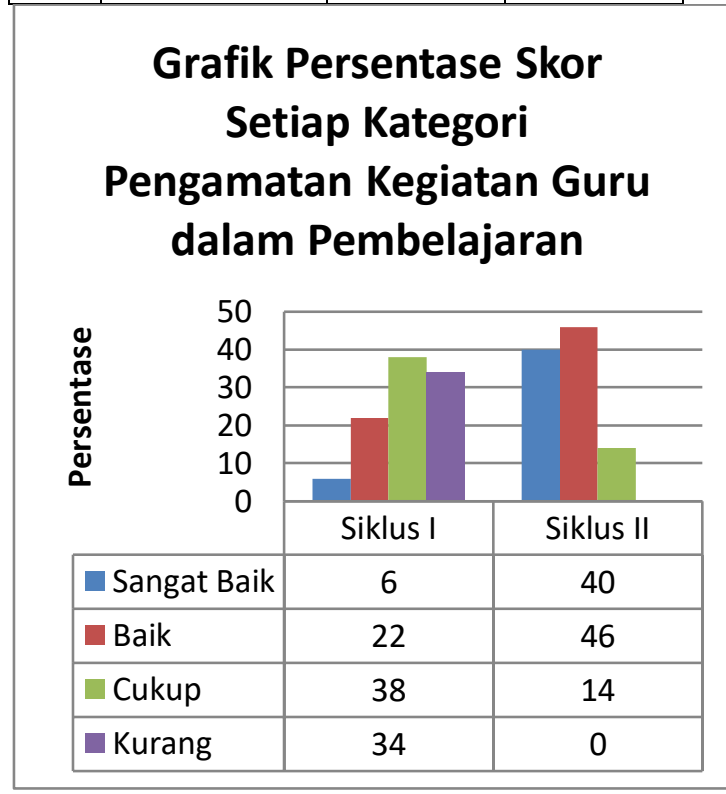

Pada tabel dan grafik menunjukkan bahwa kegiatan guru dalam pembelajaran semakin terlihat meningkat seiring dengan pergantian siklus. Dari setiap siklus I dan II meningkat menjadi $40 \%$, kategori baik $22 \%$ meningkat menjadi $46 \%$, kategori cukup $38 \%$ meningkat mejadi $14 \%$.

Kemampuan membaca awal pada siswa kelas I dengan menggunakan model pembelajaran picture and picture dan permainan kartu sehigga siswa mampu membaca hingga 5 kata, seperti yang telah diungkapkan oleh Arsyad (2000:89) mengemukakan bahwa "Media visual dapat memperlancar pemahaman dan memperkuat ingatan. Media visual dapat pula menumbuhkan minat anak dan dapat memberikan hubungan antara isi pelajaran dengan dunia nyata." Kartu huruf merupakan salah satu media pembelajaran yang dapat terlihat secara visual sehingga anak akan tertarik untuk mengikuti kegiatan pembelajaran yang dilaksanakan.

Kemampuan membaca awal dengan menyusun kartu sesuai gambar tidak lepas dari peran model pembelajaran picture and picture. seperti pendapat dari Agus (2011:125) 
Picture and picture yaitu suatu Model yang menggunakan gambar dalam bentuk potongan-potongan untuk dipasangkan serta diurutkan menjadi gambar yang utuh. ada kegiatan pembelajaran ini siswa melihat gambar anggota tubuh dan menyesuaikan dengan kartu huruf, sehingga siswa mampu menyusun dan membaca mulai dari tiga-lima huruf.

\section{D.KESIMPULAN}

\section{Simpulan}

Berdasarkan hasil penelitian dan pembahasan, maka dapat peneliti menyimpulkan sebagai berikut:

1. Pada kegiatan pembelajaran di kegiatan pada awal pembelajaran siswa masih banyak siswa yang belum bisa membaca Dan sesudah dilaksanakan siklus 1 dan 2 maka kegiatan pembelajaran siswa meningkat, disebabkan mereka suudah mulai mampu membaca dan menyusun kata

2. Hasil kemampuan membaca awal, ketuntasan siswa pada observasi awal $45 \%$ meningkat pada siklus I sebesar $60 \%$ dan pada siklus II meningkat menjadi $95 \%$. Hasil pengamatan akvitas siswa dalam pembelajaran, ketuntasan pada siklus I pada kriteria sangat baik dan baik mencapai $33 \%$ dan pada siklus II menjadi $\quad 86 \%$. Hasil pengamatan kegiatan guru dalam pembelajaran, ketuntasan pada siklus I kriteria sangat baik dan baik sebesar $28 \%$ dan pada siklus II meningkat menjadi $86 \%$.

\section{Saran}

1. Pada pembelajaran di Sekolah Dasar, guru sebaiknya menggunakan model pembelajaran Picture And Picture karena model ini dapat meningkatkan Kemampuan membaca permulaan

2. Model pembelajaran Picture And Picture salah satu model yang dapat digunakan pada mata pelajaran yang lain, yang menuntun siswa untuk bisa berbuat dan menemukan sendiri dalam bentuk perilaku.

3. Dalam pemanfaatan model pembelajaran Picture And Picture sebaiknya siswa dijelaskan secara rinci dahulu, agar pada saat model itu digunakan tidak terjadi kebingungan 
PEDAGOGIKA

Jurnal Ilmu Pendidikan

Volume 9 (Nomor 2) 2018

dan membuang waktu dengan percuma seperti pada siklus I.

4. Siswa hendaknya bisa lebih aktif dalam kegiatan pembelajaran, tidak tergantung kepada guru. Apabila ada yang tidak dimengerti bisa bertanya kepada guru atau temannya yang lebih pandai.

\section{REFERENSI}

Arsyad Azhar, "Media Pembelajaran" , PT.Raja Grafindo Persada, Jakarta

Arikunto, dkk. 2007. Penelitian Tindakan Kelas. Jakarta: Bumi Aksara

Chong, S dan Cheah, M.H. 2009. A Values, Skills and Knowledge Framework For Initial Teacher Preparation Programmes. Australian Journal of Teacher Education. Volume 34, Nomer 4
Farida Rahim. 2005. Pengajaran

Membaca di Sekolah Dasar. Jakarta:

Bumi Aksara

Jurnal Kreatif Tadulako Online Vol. 3

No. 1 ISSN 2354-614X

Kurniasih, dkk. 2015. Ragam Pengembangan Model Pembelajaran untuk Meningkatkan Profesionalisme Guru. Jakarta: Kencana

Rusman, dkk. 2011. Model-Model Pembelajaran. Jakarta: Rajagarfindo Persada.

Suprijono, Agus. 2009, Cooperatif Learning: Teori dan Aplikasi, Yogyakarta: Pustaka Pelajar.

Shoimin, Aris. 2014. 68 Model pembelajaran Inovatif dalam Kurikulum 2013. Yogyakarta: Ar-Ruzz Media 